\title{
書 評
}

\section{Stephen A. Royle : A Geography of Islands: Small Island Insularity. London and New York : Routledge 2001 237p.}

ウェーゲナーの大陸漂移説がとなえられた 20 世紀初頭のころから、最小のcontinentはオース トラリアであり、最大のislandはグリーンラン ドであるという区別が、欧米では科学的根拠の あるものとして受け入れられるようになった が、このisland概念は、日本人が伝統的にもっ ていたシマ、あるいは島嶼概念とは一致しな (1)。伝統的に日本人は、本州・四国・九州を シマとは考えてこなかったし、青函トンネルで 結ばれる以前から、北海道をも島嶼とは考えて いなかった2)。本書のサブタイトルがsmall islandの島嶼性となっているのは、世界的規模 で島嶼の比較研究をする際には、面積規模ある いは人口規模からみて、日本語のシマ概念に相 当する小さなislandに限定しなければならない からである。著者は、人口が 1 億を超す本州・ 四国・北海道や、面接が77万平方キロのニュー ギニア、23万平方キロのグレート・ブリテンを small islandとは考えていないが、明確な基準は

\footnotetext{
1) 日本人のこの島嬹概念をペルティエは「超島嶼 性」と表現している。

(Pelletier, P. 1997. La Japonè sie: Geopolitiqué et géographie historique de la surinsularité au Japon. Paris: CNRS Éditions.)

2) 日本が島国であるという表現は、明治30年代に西 洋のisland概念の影響を受けて生じたもので、近世 においては、平戸を嶋国とする用例はあっても、日 本を島国とする用例はない。(小学館『日本国語大 辞典』第二版参照)

3) やはり明確な量的基準を示してはいないが（それ
}

示されていない3)。本書で事例としてとりあげ られているsmall islandで最大のものは面積 8 千平方キロのクレ夕島である。しかし、small islandという用語はかなり熟していると考えら れ、国際島嶼学会の英語名もInternational Small Islands Studies Associationである。著者 は北アイルランド、ベルファストのクイーンズ 大学の地理学者で、アイルランドのダーシー島 を休暇に訪れたのが発端で島嶼研究を志すよう になり、地中海、オセアニア、カリブ海など世 界中の島嶼での調査歴をもつ。

「夢と現実」と題された導入の第 1 章では、 広義の文学的イマジネーションにおける島嶼を 考察の対象にし、デフォーの『ロビンソンク ルーソー漂流記』から19世紀フランス・ロマン 主義文学をへて、現代にいたるまでのヨーロッ パ文学作品の多くが、想像上の島を舞台にして いることに注目している。現実社会を痛烈に批 判した作品として、スウィフトの『ガリヴァー

は不可能であろうし、また必要もない) が、 small islandの重要性を指摘したものとして、次の 2 書が ある。

Hintjens,H.M.and Newitt, M.D.D.eds.1992.The political economy of small tropical islands:

The importance of being small. Exeter:University of Exeter Press.

King,R. and Connell,J.1999. Small worlds, global lives: islands and migration. London: Pinter. 
旅行記』が論じられているが、大航海時代以降 の海のかなたの世界への憧憬と結びついた最初 の作品としては、モアの『ユートピア』に注目 すべきではないかと評者は考える。また「海の かなたの世界への憧憬」が、ピエール・ロティ に見られるような、オセアニア・オリエンタリ ズムをつくりだしたことにも注目しなければな らないのであるが、ヨーロッパ人の著者に、そ れを期待するのは無理であるのかも知れない。 ヨーロッパ文化におけるこのような想像上の島 が、ヨーロッパの人たちの行動に影響をあたえ てきたのであるとすれば、漢字文化圈をはじめ とするその他の文化のもとにおける想像された 島の比較検討も、今後の島嶼研究における私た ちの重要な課題になるであろう。「その形成と 自然」と題された第 2 章では、プレートテクト. ニックス理論などの自然科学的観点から島嶼の 特色が説明されている。第 3 章は「過程と結 果」で、ここでは隔絶性と周辺性、弱者性 (powerlessness) および資源の 3 つにわけて 世界の多くの島を例にあげながら、島嶼性が説 明されている。この 3 つの島嶼性は相関連し、 原因ともなり結果ともなっているのであるが、 著者は島嶼のなかにも中心と周辺があり、多く の島嶼国家において、首都または主島への人口 集中がすすみ、属島では過疎化が進行している ことに注目している。また、赤道ギニアのビヨ コ島にある首都マラボ、現在は橋やトンネルで むすばれているが、シェラン島に位置するコペ ンハーゲン、ナイジャリアのラゴス島、さらに はニューアムステルダム時代のマンハッタン島 のように、本土に接近したオフショアの島嶼と いう位置が、貿易（奴隷貿易をふくむ）港とし ての繁栄にとって絶好の条件をもたらした場合 もあることに言及している。オフショア金融セ
ンターは、現在では世界各地にあるが、もとも と島嶼の隔絶性を利用したバハマとイギリス領 のケイマン諸島が、多数のペーパーカンパニー をひきつけ、ヘッジファンドの短期資金や麻薬 取引に起源するマネーロンダリング資金も、こ の種のオフショア金融センターを経由したこと にも注目する必要があろう。隔絶性を利用した 立地としては監獄（ケープタウン沖のロベン 島）などがあるし、1954年まで移民局が置かれ ていたエリス島も隔絶性を利用した事例であろ う。著者はその他冷戦構造解消後、アメリカが ミサイル核弾頭の廃棄場所にしているジョンス トン島などを、隔絶性の利用例としてあげてい る。そして、島嶼がこのようにネガティヴな立 地点になったのは、隔絶性と小規模性に由来す る弱者性にあることを著者は、沖縄（本土の周 辺に位置して戦場になった結果として、その 1 ／5の面積が今なお米軍基地である）、原水爆 実験に用いられたマーシャル諸島が例としてあ げられている。島嶼の小規模性から、その資源 利用の方法としてはAll the eggs in one basket すなわちモノカルチャー化か、多角化 (occupational pluralism) かしかないことを指 摘し、多角化の場合、そのバスケットがだめに なれば壊滅的打撃をうけることを、ソ連崩壊後 のキューバ（奇跡的に観光関連産業に活路を見 いだしている)、燐鉱資源が枯渴しつつあるナウ ルを例としてあげている。

第 4 章は「過去における島嶼」と題され、遠 隔の島嶼とくに属島の場合、「発展」の契機が ないために過去の姿がよく残っていることが指 摘され、これは柳田の周辺文化論にも通じる視 点と考えられる。第 5 章は「住民と人口移動」 で、ここでは島䝵が基本的に MIRAB (MIgration, Remittances, Aid, Bureaucracy) 
に依拠することが論じられ、人口が流出し、彼 らからの仕送り、あるいは本土または本国から の援助、公共投資、そして引退老人がうけとる 年金によって島の経済が成り立っていること が、アイルランドの島嶼部、キリバス共和国な どを事例として論じられている。さらには、多 くの島嶼国家が、累積債務をかかえ、現在、グ ローバリゼーションの名のもとに、IMF・世界 銀行によって内政干渉に類する構造調整を受け ている弱者性にも言及されてしかるべきであっ たろう。世界の島嶼で人口の流入が見られるの は、観光関連産業が非常にさかんな地中海のい くつかの島に限定され、その場合にも観光関連 産業と農業とが水資源をめぐって競合する場合 が多い。「コミュニケーションとサービス」と 題された第 6 章で注目されるのは、空港をも ち、航空路でむすばれることがフェリー以上に 重要な意味をもつことが多いこと、情報伝達手 段の飛躍的発展の結果として、島嶼でも理論的 にはテレワークが可能なはずであるが、現実に はコールセンターやバックオフィス機能が島嶼 で見られるのは、アイルランドのいくつかの島 (ニューヨークの保険会社からのアウトソーシ ングをうけている）に限られること、公共サー ビスとしては医療・保険が重要であるが、多く の島嶼にとっては淡水の供給および教育が重要 であることなどの指摘である。教育に関して は、キプロス島の分断後ギリシアとトルコの大 学が新設されたこと、いくつかの島嶼国家と海 外領で共同運営されている西インド大学

(UWI) おょび南太平洋大学 (USP) 、13の キャンパスをもつスコットランドの University of the Highlands and Islandsが例と してあげられている。

第 7 章は「政治と島嶼」と題され、フォーク
ランド諸島、竹島、尖閣諸島、南沙群島など領 有が争われている事例があげられているが、そ れが排他的経済水域の地下資源および水産資源 にからんだものであることの指摘が十分になさ れておらず、したがって世界の島嶼のなかでは まれな事例である人工物でかためられた沖ノ鳥 島に関する記述もまったくない。冷戦構造のも とでアメリカが戦略的位置に立地する島嶼を基 地化し、冷戦構造解消後それがスクラップ化さ れたことが指摘されているが、インド洋の英領 ディエゴ・ガルシア島が、石油資源をにらんだ 湾岸戦争、アフガニスタンおよびイラク攻撃に 最大限利用されていることの指摘がないことも 不満である。第 8 章は「現代における島嶼経済」 と題されて、シンガポールの下請け工業島に なっているインドネシア領バタム島、小規模性 を克服する手段としての特産品のブランド化 (マデイラ諸島のマデイラワインなど)、そして 観光関連産業の振興が論じられているが、観光 関連産業に関してはさらに次の第 9 章「観光業、 島嶼問題の普遍的な万能薬か？」で、さらに詳 しく論じられている。観光関連産業で島嶼経済 が活性化するのは、限られた条件のもとである ことが指摘されている ${ }^{4)}$ が、クルーズ船の寄港 など、日本の島嶼では大きな問題にならないこ とがとりあげられている。最後の「結論」と題 された第10章は、通常の書物の結論部とは趣を 異にして、セントヘレナ島を事例としてとりあ げ、そこにおいて本書で問題にした島嶼性がど のようになっているかを具体的に論じたもの

\footnotetext{
4) 島嶼の観光関連産業について論じた論集として は、次のものが参考になる。

Briguglio, L., Butler, R., Harrison, D. and Leal Filho, W.eds.1996. Sustainable tourism in islands and small states: Case studies. London: Pinter.
} 
で、通常の読者にとってはあまり知られていな いセントヘレナの貴重な地誌であるとともに、 本書の結論部として説得力のあるものになって いる。

すでに指摘したいくつかの不満の他に、伝統 的な自給自足経済から交換経済に移行するのに ともなって、島民の衣・食・住がどのように変 化したか、孤立・隔絶した島嶼にあってはその 変化は短期間に急激であったはずであるが、こ のような島民の生活にとって最も重要な側面に ついての記述がないのが、本書の弱点である。 しかし、世界全体を展望して島嶼性を比較検討 した類書がないなかにあって、本書は比較島嶼 論の貴重な成果があるといわなければならな w。 